\title{
WASTE TO ENERGY SOLUTION IN ANTIQUITY AND IBADAN
}

\author{
Monica O. Aneni* \\ http://dx.doi.org/10.4314/og.v14i1.7
}

\begin{abstract}
Waste to energy solution, the technology that converts municipal solid waste to energy has been discussed by several ancient and modern scholars. Several other authors have identified the types of waste as well as energy derived from such wastes, the various types of processes and the consequences of waste to energy technology in some other countries. This study examines waste to energy solution in antiquity, and proposes a modern equivalence for the sprawling metropolis of Ibadan. The paper further argues that turning waste to energy has environmental and health implications for the society. The argument being put forward in this discourse is that since ancient Greeks and Romans could take recourse to renewable energy, albeit in a rudimentary manner devoid of modern technology, it is therefore pertinent that this technology, which has become modern, be adopted to address the waste problem of Ibadan, and provide renewable energy from waste for the city. Further studies may examine how the technology can be adopted and simplified for individual personal structures, and other parts of the country.
\end{abstract}

Keywords: Waste to energy solution, antiquity, Ibadan

\section{Introduction}

Waste to energy mechanism is a process that generates energy in the form of electricity and/or heat through the combustion of municipal solid waste. Through this process, combustible fuels such as methane, methanol, ethanol or synthetic fuels are derived. These forms of energy have various implications for cities and residents of cities that adopt this technology. The methods whereby energy is derived from wastes are; incineration, thermal technologies and nonthermal technologies. Cities that have adopted this technology are generating energy that is useful and beneficial to a large number of people. The waste matter include municipal solid waste (MSW), 
industrial waste, agricultural waste and waste byproducts (Clean tech Report 2007). There are various sources of renewable energy apart from municipal solid waste. The Department of Energy (DOE) states that sources of renewable energy include; "wood and other biomass, solar (Photovoltaic and Thermal), wind, geothermal, Municipal Solid waste (MSW), Refuse-Derived Fuel (RDF), Landfill Gas (LFG)] and any other sources that are naturally or continually replenished."

Turning waste to energy in antiquity was not as sophisticated as it is in today's society. However, waste management was extensively considered for the problem of waste had become enormous such that the leaders had to adopt official and technical measures at managing municipal waste. In his epigrams, we observe how Martial (1993) informed Paulus of the measures he had to adopt in order to avoid dirt that were emptied on the streets, as he made his way through all that chaos to visit the same friend, Paulus. Citizens disposed of their waste in whatsoever method they desired. Weeber (2006) and Thommen (2012), state that some waste were thrown into sewers, pits and others, discharged onto the streets. Laws were put in place to prevent this kind of littering and also to keep pedestrians from getting injured in the process of throwing rubbish on the streets. When these habits continued, the perpetrator or the house owner was charged with a fine (Digest 9.3. (Roman Law)). Weeber (2006) noted that owners or occupants of were instructed to clean the section of the street in front of their houses at their own expense, and failure to so, incurred the wrath of the law. While waste management remained an issue, transforming waste to energy such as the combustion of wood and charcoal was experienced in antiquity. Therefore, the fact that must be considered is that the ancients understood the importance of renewable energy from waste and did transform natural resources into energy. Evidence of such is observed in some works of some ancient authors. However, as civilizations evolved, sophisticated methods of producing energy and from waste were and are being invented and utilized for the growth of society.

Several other modern scholars have studied and do study waste to energy solutions (WtE) adopted by several countries in today's world and how beneficial they have become for their societies. Rehan et al. (2017) stated that multi fuels and value-added 
products can be derived from various fractions of municipal solid waste. They identified the following energy recovering technologies as anaerobic digestion (AD), pyrolysis, transesterification, refuse derived fuel (RDF) and incineration. They also set out to study two waste-to-energy technologies, $\mathrm{AD}$ and pyrolysis and their implications for the city of Madinah. The implications include; 15.64 and 58.81 MW from biogas and pyrolytic oil or a total 74.45 MSW of continuous electricity supply in Madinah city throughout the whole year. They postulated that the development of AD and pyrolysis technologies will also benefit the economy with net savings of about US $\$ 63.51$ and US $\$ 53.45$ million respectively, totaling an annual benefit of US \$116.96 million. Again, Mova D. et al. (2017) studied the potential of energy from mineral solid waste in the city of Quito in Ecuador. Having noted that the MSW of Quito contained $69.3 \%$ of biodegradable waste and $30.7 \%$ of nonbiodegradable waste with putrescible waste accounting for $81.4 \%$ of biodegradable waste, they arrived at the conclusion that the mineral solid waste from Quito has potential for producing biogas and heat energy. It may be only a matter of time, the city of Quito is not far from adopting this waste to energy solution for the progress of her society. The above various studies, among others, demonstrate the importance of the waste-to-energy solutions and the many countries that are adopting and utilizing the technology for the betterment of their societies. However, studies that examine $\mathrm{WtE}$ solutions and the adoption of a waste-to-energy mechanism in antiquity and for the metropolis of Ibadan are scanty. This study sets out to give a history of waste to energy solution in antiquity, however brief, and to expound the importance of this technology for the city of Ibadan with a view to understanding the resources this technology reined in for antiquity, and would rein in for Ibadan in particular, and Nigeria in general.

\section{Methodology}

The study adopts a historical methodology. A history of waste-toenergy processes and its successes in antiquity and in other modern societies that have adopted this mechanism are noted in the study. 


\section{Theoretical framework}

The idea of converting waste to energy may have been borne out of man's desire to move from one stage of development to another. This stage is to discover and invent methods to solve the problem of air pollution that cause diseases as a result of accumulated and decomposing waste. Therefore the theory of social development explains this phenomenon.

Jacobs et al. (1999) defines social development as a process of social change that is ascending with regard to greater levels of energy, quality, productivity, complexity, efficiency, comprehension, creativity, mastery, enjoyment and accomplishment. This theory explains that the driving force behind social change is the desire to establish and operate an organized system. Therefore, as soon as a society establishes a motive to make it better, she harnesses all available social energies, skills and resources to arrive at a profitable conclusion for all in the society. This motive must be formidable enough to overcome challenges and obstructions that usually accompany or may impede new mechanisms or technologies. The pace of decision-making and the capacity to undertake and establish developments for the prosperity of a society differ from one to the other. However, development would occur when society organizes resources to solve her challenges in certain social, economic and political spheres. This social development was witnessed in the ancient Roman society as she evolved into several eras such as the Monarchical, Republican, Principate and the Dominate eras in various aspects of the culture. The same is also evidenced in Ibadan. However, with regard to renewable energy from municipal solid waste, the idea that Ibadan should attain such development is being $\mathrm{s}$

\section{Significance of the study}

This study makes significant contribution to knowledge as it demonstrates this mechanism in antiquity, and deconstructs the waste to energy solution for the city of Ibadan, and adds to the extant body of knowledge on cities and countries that have adopted and indeed benefitting from this technology. 
Waste to Energy Solution...

\section{Waste to Energy Technologies in Antiquity}

Several modern authors have discussed waste management and the transforming of waste into energy in antiquity. Havlicek\&Morcinek, (2016) mention that Rome, due to its increasing urbanization produced higher amount of waste as they attempted to discuss the perception of waste and waste management in the Roman Empire. Dearne and Branigan (1995) stated that cereal chaff, dung, coal and animal waste were transformed to produce energy in the Roman Empire. Rowan (2015), discussed the effectiveness of pomace as a domestic and industrial source of fuel in antiquity. Of the various types of waste which were transformed into energy in antiquity, pomace was in high demand due to its effectiveness. Pomace is the waste or solid material derived from olive oil after undergoing the process of pressing. This pomace is also referred to as olive pomace or olive mill cakes or jift in Arabic or grignons in French (Galiliet al. 1997; Tekin and Dalgiç 2000; Mekkiet al. 2006, Niaounakis and Halvadakis 2006). Pomace has gained popularity with scholars due to its usage as a fuel source or means of energy in antiquity such that some scholars referred to it as a by-product rather than waste from olive oil production. In describing pomace, Karapmar and Worgan (1983) noted that it is a combination of olive flesh, skin, stones (endocarp) and seeds, and that it contains 3.5-12.0\% olive oil and 20-30\% water. Mekki et al. (2006) documented that the pressing of one ton of olives produces 200 litres of olive oil and $350-400 \mathrm{~kg}$ of pomace. This pomace was used as fuel source in the pre-Roman era (Mattingly, 1988) and in the Hellenistic era (Fasnacht et al.1996). In the Roman period, pomace was used as fuel in the production of pottery, mortar, olive oil and bread, even at an industrial level (Smith, 2001; Lewit, 2011).

Some of the literature on waste to energy solutions in antiquity demonstrates the results of archaeological excavations with regard to the use of pomace, wood, charcoal, animal dung and others. It is pertinent to note that the technology, irrespective of how rudimentary, was utilized to transform waste to energy. Furthermore, ancient leaders understood and utilized effective skills to exploit natural resources and garbage or trash and transformed them to energy through the use of water, heat and oil. Through such technology, ancient Romans could execute the business of importation of products such as grains, silk and others from Africa 
and the Near East. Some other times, ancient Romans derived energy, not necessarily from waste, but from other sources such as water, wind, coal and oil. They utilized energy from water to grind corn, cut wood, forge iron, power clocks and create music using special organs. Suetonius tells us that the Emperor Nero was a proficient player of water organ. Vitruvius (X. 5.2), Ammianus Marcellinus (The Res Gestae 18.8.11) and Pliny the Elder (Natural History XVIII, 23.97) did mention the use of watermills as a source of energy in antiquity. We also learn from Pliny the Elder that gold mining depended on water power to eliminate waste debris and power primitive machines. Charcoal, which is waste from burnt wood, was used in the production of glass and metals.

It is also a fact, that the ancients had landfills where they dumped refuse. Waste management in antiquity was deplorable, until a period when leaders had to adopt methods at ensuring cleanliness and hygiene in the society. Hughes (2001) tells us that Emperors Augustus and Aurelian ensured that the River Tiber, where a lot of waste was deposited, was cleaned and its channel widened. Augustus appointed some men to inspect the river and her banks. By the time, Trajan began his reign, this group's duties included managing the sewage system. Recycling refuse was not common place, but ensuring that refuse was properly disposed of took the front burner. In spite of the fact that the ancient Greek and Roman societies were not as developed as today's modernity, some refuse were recycled to produce energy. The combustion of wood and other fragments of some items produced heat for warmth and some others were used in erecting buildings in the city. As societies desired and continued to develop, a modern idea was birthed and it is harvesting positive products that are beneficial to man and his environment. One of such ideas is the modern method of transforming waste to energy in the 2 ist century.

\section{Waste to Energy Technologies in Today's World}

The most common technology of converting waste to energy is combustion via incineration. Through incineration, organic substances in waste materials undergo combustion and consequently, the waste is converted into ash, flue gas and heat. The different types of incinerators are rotary kiln, fludized bed, liquid injection, multiple hearth, catalytic combustion, waste-gas flare and direct- 
Waste to Energy Solution...

flame. As important as incinerators are with regard to converting waste to energy, there are concerns about their emissions. The concerns are emissions from the incinerators and the proper management of residues such as toxic fly ash and bottom ash. It is noted that the emissions such as fine particulate, heavy metals, trace dioxin and acid gas, are relatively low (Ministry of Environment of Denmark, 2006). Knox (2005) noted that this incineration method faces criticisms due to pollution resulting from the exhaust gases that are by-products of the procedure. However, he further stated that in spite of this complaint, incinerators are still being utilized since recent developments in the field of air pollution control have made incineration a much more attractive option. Due to abiding and applying world's best practices in the area of emissions from incinerations, emissions from some incinerators can be cleaner than the ambient air. The European Union (EU) directive is that incinerators, whether commercial or industrial must meet emission standards, including those of nitrogen oxides (NOx), sulphur dioxide $\left(\mathrm{SO}_{2}\right)$, heavy metals and dioxins. The point to note here is that, while nations are thinking renewable energy, scholars are thinking better methods at achieving this for their societies. Directives are being established to ensure that world's best practices are adopted as attempts are made at social development.

\section{Thermal Technologies}

Other technologies are thermal and non-thermal. Thermal technologies include; gasification, Pyrolysis, Thermal Depolymerization and PGP (Plasma Arc Gasification). Non-thermal technologies are; anaerobic digestion, mechanical biological treatment, MBT + anaerobic digestion, fermentation and MBT to Refuse Derived Fuel (Waste Management resources, sourced 12/02/2018). Arena U. (2012), Chen D, et al. (2014), Lombardi L, et al. (2015) and UCR (2009) present the following emerging approaches to deriving energy from waste; gasification, plasma gasification, and pyrolysis. Proponents of these approaches believe that these methods would produce outputs such as cleaner emissions, flexibility and the elimination of landfilling. Thermal technology, a method of turning waste to energy, is the super heating of a feedstock such as mineral solid waste, coal or agricultural waste in an oxygen controlled environment. This can be achieved through 
gasification, pyrolysis, thermal depolymerization and PGP (Plasma Arc Gasification). Gasification converts organic-fuel based carbonaceous materials into gases such as carbon monoxide, hydrogen and carbon dioxide through a controlled amount of oxygen. Energy is derived from the gasification of compounds obtained from biomass (National Non-Food Crops Centre, 2011). Thermal depolymerization uses hydrous pyrolysis to reduce complex organic materials such as waste products or biomass to produce energy. This procedure breaks down chemical bonds and destroys pathogens. It can also remove heavy metals by converting them to their stable oxides from their ionized forms. Alemánet al. (2007), defines pyrolysis as the thermal breakdown of materials such as wood, starting at $200-300^{\circ} \mathrm{C}\left(390-570{ }^{\circ} \mathrm{F}\right.$ (Burning of Wood, sourced 14/02/2018) in a controlled nitrogen gassed environment. Pyrolysis converts biomass into syngas and biochar. It also converts waste plastic into usable oil or converts waste into safely disposable substances.

\section{Non-thermal Technologies}

Non-thermal technologies are; anaerobic digestion, mechanical biological treatment, MBT + anaerobic digestion, fermentation and MBT to Refuse Derived Fuel (Waste Management Resources. Sourced on 12/02/2018). Anaerobic digestion is used to process renewable energy from wastes and so produces biogas that consists of methane, carbon dioxide and other gases. This biogas can be utilized as fuel in power gas engines. Mechanical biological treatment are plants designed to process household, industrial and commercial wastes to energy.Totoraet al. (2010) defines fermentation as any metabolic process that releases energy under anaerobic conditions. Refuse derived fuel is produced from municipal solid waste using a blend of mechanical and or biological treatment methods. The process of refuse derived fuel include the following: preliminary liberation; size screening; magnetic separation; air classifier, pelletizing, coarse shredding and refining separation by infrared separation (Ganesh et al. 2013). A pertinent point to note is that thermal and non-thermal technologies have been adopted by several countries who are transforming waste into energy. 
Waste to Energy Solution...

\section{Countries Utilizing Waste to Generate Energy}

Some countries are already in the forefront of utilizing waste to generate energy. The International Solid Waste Association (2006) noted that, as at 2004 and 2005, there were 89 and 431 waste to energy plants in the United States and in Europe respectively. Two of such plants have been launched in Africa. Abdur Rahman Alfa Shaban (2018) reported that Ethiopia launched the first Africa's waste to energy facility. He stated that the facility was constructed in 2013 on the Koshe landfill site that was located on the borders of Addis Ababa. John Owen Nwachukwu (March 19, 2019) reported that the University of Nigeria Nsukka (UNN) launched a Refuse Derived Fuel (RDF) gasification plant on the $18^{\text {th }}$ of March, 2019. The 100KVA plant uses organic waste for electrification of the Nsukka Campus. The head of the research team, Prof Emenike Ejiogu, that produced this RDF gasification plant, stated that since the UNN power demand was $3 \mathrm{mgwats}$, the team was set to produce twelve 250KVA of RDF plants that would meet the energy need of the University. Some other countries that are utilizing renewable energy from waste are; Sweden, United Kingdom, United States, Portugal, Canada and several others. Sweden is known to have several incineration plants for generating energy. The Swedish Waste Management Association reports that 4,783,000 tonnes of household waste was managed in 2017 and that 50 percent of household waste was turned into energy, thereby reducing landfills and the consequent emissions that are hazardous to the environment and people. Sweden's energy generated from wastes do power or heat up several homes in the city. Denmark, Germany, the United Arab Emirates and Norway are turning waste to energy and consequently, they have reduced their dependence on fossil fuels, and a reduction of wastes at landfills is being witnessed. In Campania in 2009, an incineration that cost about 350 million euros was installed. This incinerator burns about 600,000 tons of waste in a year. It is believed that the amount of energy produced is enough to power 200,000 households in a year. Israel launched its Refuse Derived Fuel plant in 2017 at the Hiriya Recycling Park with the intent of managing waste in the society. Several other countries have begun the process of renewable energy with waste as one of the sources. Ancient Greeks and Romans turned waste to energy, albeit in a rudimentary manner, modern cities are already adopting the 
method, Ibadan must dare to pick up the pace in this social development lane.

Below is a model of a waste to energy plant

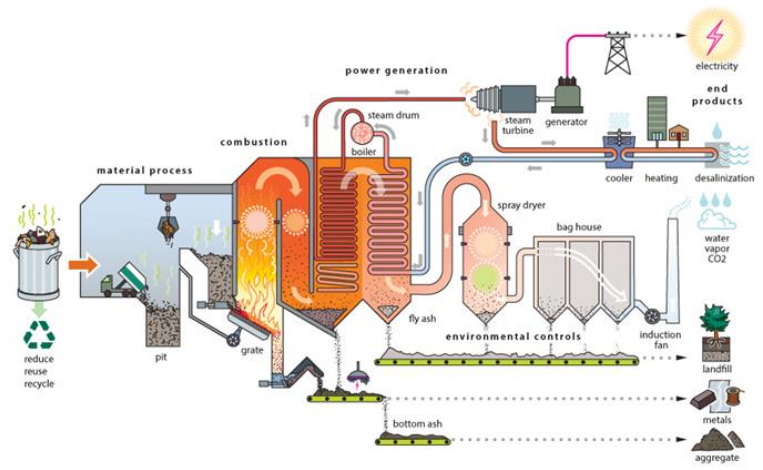

Fig. 1: Waste to energy plant. Source: http://deltawayenergy.com/

\section{Benefits of Waste to Energy Solutions}

The effects of waste to energy in contemporary societies cannot be overemphasized. Waste to energy solutions solve the problem of accumulating large landfills of waste and of course, the emission of methane to a level that it becomes harmful to man and his society. Lee et al. (2017) noted that turning food waste to energy is beneficial for man, because it generates less greenhouse gases. They noted that in 2015, the amount of greenhouse gases from landfills equaled about 116 million metric tons of carbon dioxide. Carbon dioxide, the most prevalent of greenhouse gases, and methane do cause global warming. With renewable energy, global warming emissions become minimal.

\section{Public Health is Improved}

Energy sources from wind, solar, hydroelectricity and biomass fuel do power homes, vehicles and business without the use of fossil fuels. Consequently, greenhouse gas emissions are reduced, as well as the reduction of air pollutants which are hazardous to public health. It is a well-known fact that emissions from coal and natural gas do pollute the air and so cause complications such as breathing problems, heart attacks, cancer, neurological damage and premature 
Waste to Energy Solution...

death (Epstein et al., 2011). However, adopting the waste to energy solutions helps in improving the public health.

\section{Job Creation}

The production of renewable energy is labour intensive. Therefore, more job opportunities become available. In some countries where renewable energy is being hugely utilized, thousands of people work in such organizations. In a few years to come, when renewable energy would be in high demand, many jobs would be created and society would witness considerable reduction in job cuts.

\section{Conclusion}

Waste to energy solutions has been solving the problems of waste in antiquity and many modern societies and its benefits cannot be overemphasized. Ancient societies did transform waste to energy for the benefit of their societies. For the ancient Greek and Roman societies, waste and natural resources were transformed into energy. Pomace, which is waste from olive oil pressings served as fuel for domestic and industrial needs. The ancients could propose such idea because the desire for progress and prosperity must have ignited their intellect to consider such options. The ancients could adopt such method even in an antiquated format, modern society, especially Ibadan can adopt modern techniques of accumulating energy, even from waste such that many homes are powered with electricity from this source, among others. Further studies may examine how the technology can be adopted, and simplified also for individual personal structures in Ibadan and other parts of the country.

*Monica O. Aneni, Ph.D., Department of Classics, University of Ibadan, anenimonica@gmail.com 


\section{REFERENCES}

Abdur Rahman Alfa Shaban. (2018). Ethiopia opens Africa's first waste-to-energy facility.

Alemán, J. V. Chadwick, A. V, He, J. Hess, M., Horie, K. Jones, R. G., Kratochvíl, P., Meisel, I., Mita, I., Moad, G., Penczek, S., Stepto, R. F. T. (2007). Definitions of terms relating to the structure and processing of sols, gels, networks, and inorganic-organic hybrid materials (IUPAC Recommendations 2007). Pure and Applied Chemistry. Volume 79, Issue 10, Pages 1801-1829, ISSN (Online) 1365-3075, ISSN (Print) 0033-4545, DOI: https://doi.org/10.1351/pac200779101801.

Arena U. (2012). Process and technological aspects of municipal solid waste gasification. A review. Waste Manage 32(4):625-639.

Burning of Wood. Sourced on 14/02/2018 from http://virtual.vtt.fi/virtual/innofirewood/stateoftheart/databas e/burning/burning.html

Chen D, et al. (2014). Pyrolysis technologies for municipal solid waste: a review. Waste Manage 34(12):2466-2486.

Dearne, M.J., and Branigan, K. (1995). The Use of Coal in Roman Britain. Antiquaries Journal 75:71-105.

DigestorumSeuPandectarum (Dig.) Book 9.3. Sourced on 20/02/2019 from https://droitromain.univ-grenoble alpes.fr/Corpus/d-09.htm\#3

Epstein, P.R., Buonocore, J.J., Eckerle, K., Hendryx, M., Stout III, B.M., Heinberg, R., Clapp, R.W., May, B., Reinhart, N.L., Ahern, M.M., Doshi, S. K., and Glustrom, L. (2011). Full cost accounting for the life cycle of coal. In: Ecological Economics Reviews. Annals of the New York Academy of Science. 1219: 73-98.

European Union. (2004). Directive 2000/76/EC of the European Parliament and of the Council of 4 December 2000 on the Incineration of Waste. 
Fasnacht, W., Kunz, J., Deslex, C., Zubler, K., Boll, P.O., Kassianidou, V., Connolly, A., and Maradi, T. (1996). Excavations at AgiaVarvara-Almyras: Fifth Preliminary Report. Report of the Department of Antiquities Cyrus. 95126.

Galili, E., Stanley, D.J., Sharvit, J., and Weinstein-Evron, M. (1997). Evidence for Earliest Olive-Oil Production in Submerged Settlements off the Carmel Coast, Israel. Journal of Archaeological Science. 24:1141-50

Ganesh,T., Vignesh, P., Arun Kumar, G.(2013). Refuse Derived Fuel To Electricity. International Journal of Engineering Research \& Technology (IJERT) Vol. 2 Issue 9. 2930-2932

Havlicek, F. \&Morcinek, M. (2016). Waste and pollution in the ancient Roman Empire. Journal of Landscape Ecology. Vol. 9: No 3. Pp 33-49. https://www.africanews.com/2018/08/20/the-reppie-projectethiopia-opens-africa-s-first-waste-to-energy-facility// sourced on 12/01/2019

Hughes, J. D. (2001). An Environmental History of the World.Routledge. London.

Jacobs, Garry and Asokan N. (1999). Towards a Comprehensive Theory of Social Development. In: Human Choice. World Academy of arts and Science, USA.

John Owen Nwachukwu. (19 March, 2019). UNN sets record, generates electricity from organic waste. http://dailypost.ng/2019/03/19/unn-sets-record-generateselectricity-organic-waste/

Karapmar, M., and Worgan, J.T. (1983). Bioprotein Production from the Waste Products of Olive Oil Extraction. Journal of Chemical Technology and Biotechnology 33:185-88 
Ogirisi: a new journal of African studies vol. 142018

Knox, Andrew (February 2005).An Overview of Incineration and EFW Technology as Applied to the Management of Municipal Solid Waste (MSW). University of Western Ontario

Lee, U., Han, J., Wang, M. (2017). Evaluation of landfill gas emissions from municipal solid waste landfills for the lifecycle analysis of waste-to-energy pathways. Journal of Cleaner Production. 166: 335 DOI:

Lewit, T. (2011). Dynamics of Fineware Production and Trade: The Puzzle of Supra-regional Exporters. Journal of Roman Archaeology. 24:313-32.

Lombardi L, et al. (2015). A review of technologies and performances of thermal treatment systems for energy recovery from waste. Waste Manage 37:26-44.

Martialis, M. V. (1993). Epigrams. Translated by D.R. Shackleton Bailey. Loeb Classical Library.

Mattingly, D.J. (1988). The Olive Boom: Oil Surpluses, Wealth and Power in Roman Tripolitania. LibSt 19:21-42.

Mekki, H., Anderson, M., Amar, E., Skerratt, G.R., and BenZina, M. (2006). Olive Oil Mill Waste Water As a Replacement for Fresh Water in the Manufacture of Fired Clay Bricks. Journal of Chemical Technology and Biotechnology 81:1419-25

Ministry of the Environment of Denmark. (2006). Emmissionsfaktorer.orgemmissionsopgorelse for decentralkraftvarme, Kortlægningafemissionerfradecentralekraftvarmeværker.

Mova, D., Aldas, C., Jaramillo, D., Jativa, E., Kaparaju, P. (2017). Waste-To-Energy Technologies: an opportunity of energy recovery from Municipal Solid Waste, using Quito - 
Waste to Energy Solution...

Ecuador as case study. Energy Procedia. Vol 134, pp 327336.

National Non-Food Crops Centre. (2011). Review of Technologies for Gasification of Biomass and wastes, NNFCC project 09/008.

Niaounakis, M., and Halvadakis, C.P. (2006). Olive Processing Waste Management: Literature Review and Patent Survey. 2nd ed. Oxford: Elsevier

Pliny the Elder. (1945). Natural History, Book xxxiii. Translated by H. Rackham, Loeb Classical Library.

Rehan, M., Nizami, A., Asam, Z., Ouda, O.K.M., Gardy, J., Raza, G., Naqvi, M., Ismail, I.M. (2017). Waste to Energy: A Case Study of Madinah City. Presented at the 9th International Conference on Applied Energy, ICAE2017, 21-24 August 2017, Cardiff, UK.

Rowan, E. (2015). Olive oil pressing waste as fuel source in antiquity. American Journal of Archaeology. Vol. 119, No 4. Pp 465-482

Smith, W. (2001). Environmental Sampling (1990-1994). In Leptiminus (Lamta): The East Baths, Cemeteries, Kilns, Venus Mosaic, Site Museum and Other Studies. Report No. 2, edited by L.M. Stirling, D.J. Mattingly, and N. Ben Lazreg, 420-41. JRA Suppl. 41. Portsmouth, R.I.: Journal of Roman Archaeology.

Stringfelow, T. January 13, 2014. An Independent Engineering Evaluation of Waste-to-Energy Technologies. Renewable Energy World. Sources from http://www.renewableenergyworld.com/articles/2014/01/anindependent engineering-evaluation-of-waste-to-energytechnologies.html on 12/02/2018.

Suetonius. (2009). The Lives of the Caesars. Translated by Catharine Edwards. Oxford University Press. 
Tekin, A.R., and Dalgiç, A.C. (2000). Biogas Production from Olive Pomace. Resources, Conservation and Recycling. 30:30113.

The Cleantech Report. (2007). Waste to Energy. Lux Research Inc.

Thommen, L., (2012). An environmental history of ancient Greece and Rome. Cambridge University Press.

Tortora, Gerard J.; Funke, Berdell R.; Case, Christine L. (2010). "5". Microbiology An Introduction (10 ed.). San Francisco, CA 94111, USA: Pearson Benjamin Cummings. p. 135. ISBN 978-0-321-58202-7

UCR. Evaluation of Emissions From Thermal Conversion Thermal Conversion Technologies Processing Municipal Solid Waste and Biomass. (21 June 2009). Riverside, CA:University of California, Riverside. Available: http://dpw.lacounty.gov/epd/socalconversion/pdfs/UCR_Em issions Report 62109.pdf

Waste Management Resources. Sourced on 12/02/2018 from http://www.wrfound.org.uk/articles/waste-to-energy.html

Weeber, K.W. (2006). "Refuse." Brill's New Pauly. Antiquity volumes edited by: Hubert Cancik and Helmuth Schneider. Brill Online, 2015. Reference. Masaryk University Masarykova.

Working Group on Thermal Treatment of Waste. (2006). Energy from Waste State-of-the-Art Report 5th Edition. International Solid Waste Association Working Group on Thermal Treatment of Waste. Denmark.

Wrigley E.A. (2002). The Quest for the Industrial Revolution. Proceedings of the British Academy 121, 147-170. 